\title{
Transformasi Bentuk Dan Pola Ruang Komunal Di Kota Lama Semarang
}

\section{Transformasi Bentuk Dan Pola Ruang Komunal Di Kota Lama Semarang}

\author{
Bambang Setioko *), Bangun IR Harsritanto *) \\ ${ }^{*}$ Departemen Arsitektur Fakultas Teknik, Universitas Diponegoro Semarang
}

\begin{abstract}
Abstrak
Pembentukan citra sebuah kawasan kota tua tidak hanya sekedar dilihat dari kualitas fisik bangunannya saja, akan tetapi juga dilihat dari kualitas fisik lingkungan yang diikuti dengan fungsi sosial lingkungan. Fungsi sosial lingkungan ini dapat terwujud dalam bentuk ruang komunal.Ruang komunal di kota lama Semarang adalah taman srigunting (yang sebelumnya merupakan permakaman, halaman gereja, tempat pedagang kaki lima) dan polder tawang (yang sebelumnya halaman stasiun, terminal, lapangan sepakbola. Fenomena tersebut menunjukkan bahwa telah terjadi perubahan/transformasi ruang komunal di kawasan Kota Lama Semarang. Penelitian ini bertujuan untuk untuk memperkaya teori transformasi spasial yang berkaitan dengan bentuk dan pola ruang komunal. Penelitian ini menggunakan pendekatan penelitian kualitatif. Selain itu, metode pengolaan data dilakukan dengan metode studi kasus dan analisa deskriptif kualitatif.Berdasarkan hasil analisis penelitian, ditemukan bahwa terjadi transformasi bentuk dan pola ruang komunal di Kota Lama Semarang. Kemudian, transformasi tersebut terjadi pada beberapa hal, yaitu: fungsi, bentuk, sirkulasi,aktivitas, dan identitas ruang komunal.
\end{abstract}

Kata Kunci : transformasi, ruang komunal, transformasi spasial, kota lama

\section{Pendahuluan}

Banyak kota yang memiliki nilai rasa pada tempatnya dan identitas budaya pada sepanjang perkembangan sejarahnya. Sebagian besar kualitas kota tua merupakan bagian yang tidak terpisahkan dari citra kota dan identitas kota.Pembentukan citra sebuah kawasan kota tua tidak hanya sekedar dilihat dari kualitas fisik bangunannya saja, akan tetapi juga dilihat dari kualitas fisik lingkungan yang diikuti dengan fungsi sosial lingkungan. Fungsi sosial lingkungan ini dapat terwujud dalam bentuk ruang komunal.

Kota Lama Semarang merupakan citra visual yang menyajikan kemegahan arsitektur Eropa di masa lalu. Lokasi Kota Lama Semarang yang terpisah dengan lansekap mirip seperti kota di Eropa serta kanal yang mengelilinginya menjadikan Kota Lama seperti miniature Belanda di Semarang. Oleh sebab itu, Kota Lama dijuluki sebagai "Little Netherland" di Semarang. Selain itu, pusat dari kawasan Kota Lama berada di Taman Srigunting, sebuah taman yang terletak di jantung Kawasan Kota Lama Semarang. Di masa lalu taman ini adalah sebuah lapangan bernama Parade Plein dan digunakan untuk parade militer, karena tak jauh dari sana terdapat sebuah barak militer. Sebelum menjadi lapangan, taman ini memiliki fungsi sebagai kerkhof atau pemakaman warga Eropa. Namun, seiring dengan perkembangan zaman, ruang komunal yang merupakan pusat dari kawasan Kota Lama Semarang ini berubah bentuk menjadi taman. Selain itu, tidak hanya sekedar taman, tetapi juga saat ini di taman yang dikenal sebagai Taman Srigunting ini juga seringkali digunakan oleh pedagang kaki lima untuk berjualan dan juga sering digunakan sebagai lahan parkir bagi pengunjung taman ini. Selain itu, saat ini taman ini juga sering digunakan oleh masyarakat maupun komunitas tertentu untuk saling berinteraksi sosial.

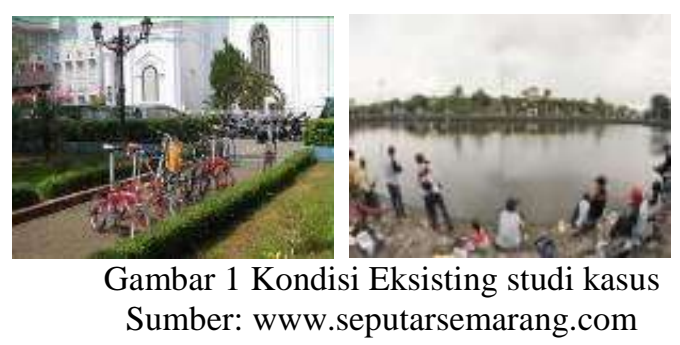

Selain taman Srigunting, ruang komunal yang memiliki peranan penting dalam sejarah kawasan Kota Lama Semarang adalah area sekitar Polder Air Tawang. Sebelum menjadi polder, dahulu area ini merupakan lapangan. Namun, untuk mengurangi banjir yang sering melanda Semarang, maka lapangan ini berubah fungsi menjadi polder sebagai pusat pengendali banjir dan penampungan air sebelum dialirkan ke laut. Namun, saat ini polder Tawang berfungsi tidak hanya sebagai pengendali banjir, akan tetapi juga sebagai area rekreasi bagi 
Transformasi Bentuk Dan Pola Ruang Komunal Di Kota Lama Semarang

masyarakat di sekitarnya. Banyak warga sekitar yang memanfaatkan Polder Tawang sebagai tempat berolah raga, berjalan-jalan sambil menikmati nuansa bangunan-bangunan Eropa di Kota Lama, dan juga sebagai area pemancingan bagi masyarakat setempat.

Fenomena tersebut menunjukkan bahwa telah terjadi perubahan/transformasi ruang komunal di kawasan Kota Lama Semarang. Dengan demikian, diperlukan sebuah penelitian yang menkaji mengenai transformasi perubahan bentuk dan pola ruang komunal yang ada di kawasan Kota Lama Semarang. Penelitian ini menggunakan pendekatan penelitian kualitatif. Selain itu, metode pengolaan data dilakukan dengan metode studi kasus dan analisa deskriptif kualitatif.Berdasarkan hasil analisis penelitian, ditemukan bahwa terjadi transformasi bentuk dan pola ruang komunal di Kota Lama Semarang. Kemudian, transformasi tersebut terjadi pada beberapa hal, yaitu: fungsi, bentuk, sirkulasi,aktivitas, dan identitas ruang komunal.

\section{Kajian sebelumnya}

Penelitian awal dilakukan pada tahun 2009 berjudul : The Methamorphosis of a Coastal city (Case study Semarang Metropolitan), telah menemukan pola perubahan bentuk kota pantai. Temuan penelitian ini telah dipublikasikan pada International Conference on Coastal Planning, Architecture and Tourism 2008 dan diterbitkan pada Journal of Coastal Development. Volume Juni/2010.This Journal is an official Journal of ISOI (Indonesian Association of Oceanologist), a nationally accredited journal based on the Decree of Director General of HigherEducation: July 15, 2009 No.83/DIKTI/Kep/2009.

Penelitian berikutnya dilakukan pada tahun 2010 berjudul: The Transformation of Urban Space in Fisherman Settlement (With case study Tambak Mulyo - Semarang Coastal Area), telah menemukan gambaran utuh tentang transformasi ruang publik. Temuan penelitian ini telah diterbitkan pada Jurnal Tata Loka. Vol.15, Page: 184-199ISSN: 0852-7458. Published by: Department ofUrban and Regional Planning Diponegoro University - Indonesia joint with Indonesian Planning Association, a nationally accredited journal based on the Decree of Director General of Higher Education: 1st November, 2010 ;No.64a/DIKTI/Kep/2010.

Kemudian penelitian juga dilakukan pada tahun 2014 berjudul: Transformasi Ruang Publik di Permukiman Nelayan 'Bontang Kuala'(studi kasus Pesisir Kota Bontang), telah menemukan gambaran utuh transformasi ruang publik. Dari temuan penelitian ini dapat disimpulkan bahwa transformasi ruang publik di permukiman nelayan " Bontang Kuala" terjadi akibat perubahan

aktivitas masyarakat yang awalnya sebagai nelayan,kini ruang public di pesisir kota Bontang berubah fungsi menjadi tempat karaoke dan restoran, sehingga ciri permukiman nelayan "Bontang Kuala" sebagai permukiman pesisir menjadi hilang.

\section{Ruang Komunal}

Ruang komunal merupakan ruang yang bersangkutan dengan wilayah tertentu yang ditandai oleh pemilikan dan pemakaian secara bersama-sama pada kelompok ter- tentu. Ruang komunal juga dapat diartikan sebagai ruang tempat manusia melakukan aktivitasnya secara bersama. Ruang komunal dapat berupa taman, jalan umum, atrium, ruang tunggu, serta ruang-ruang umum lain baik indoor maupun outdoor,baik yang dikelola oleh pemerintah, swasta, maupun masyarakat (Santoso, 2009).

Menurut Carr,et all (1995) terdapat beberapa hal yang menyebabkan terjadinya perubahan pada ruang komunal, yaitu sebagai berikut: [1] sejarah awal,[2] fungsi ruang komunal ,[3] aktivitas di sekitar ruang komunal,[4] set back di area sekitar ruang komunal,[5] bentuk bangunan yang ada di sekitar ruang komunal.

\section{Perubahan bentuk ruang komunal}

Menurut (Girouard, 1985) wujud perubahan ruang komunal dapat berupa: [1] bentuk lansekap ,[2] benteng air,[3] panggung,[4] zona relaksasi,[5] restoran,[6] detil arsitektur,[7] jalur sirkulasi di dalam ruang komunal.

Menurut Carmona, et all ( 2006) bentuk perubahan ruang komunal adalah sebagai berikut:[1] Angling, [2] Addition, [3] Regular, [4] Irregular, [5] Closed, [6] Open

Menurut (Zahnd, 1999) terdapat 6 pola dan dimensi unit perkotaan yaitu sebagai berikut: [1] Angular, [2] Aksial,[3] Grid, [4] Kurva Linier,[5] Radial Kon sentrik,[6] Organis.

Menurut Ching (1979) transformasi yang terjadi pada bentuk trimatra dibagi menjadi 3. Yaitu :

1. Transformasi Dimensional : perubahan dari salah satu dimensi panjang, lebar, maupun tebal bentuk

2. Transformasi Substraktif : perubahan dengan mengurangi volume dari bentuk

3. Transformasi Additif : perubahan dengan menambah elemen pada bentuk 


\section{Transformasi Bentuk Dan Pola Ruang Komunal Di Kota Lama Semarang}

\section{Hubungan visual antar ruang kota}

Trancik (1986) menjelaskan bahwa dalam linkage yang visual dua atau lebih fragmen kota dihubungkan menjadi satu kesatuan yang secara visual,mampu menyatukan daerah kota dalam berbagai skala. Pada dasarnya ada 2 pokok perbedaan antara linkage visual,yaitu:

1. Yang menghubungkan dua daerah secara netral

2. Yang menghubungkan dua daerah,dengan mengutamakan satu daerah

Lima elemen linkage visual,merupakan elemen yang memiliki ciri khas dan sua- sana tertentu yang mampu menghasilkan hubungan secara visual,terdiri dari:

a) Garis: menghubungkan langsung dua tempat dengan satu deretan massa (bangunan atau pohon).

b) Koridor: dibentuk oleh dua deretan massa (bangunan atau pohon) yang mem- bentuk sebuah ruang.

c) Sisi: menghubungkan dua kawasan dengan satu massa. Mirip dengan elemen garis namum sisi bersifat tidak langsung.

d) Sumbu: mirip dengan elemen koridor,namun dalam menghubungkan dua daerah lebih mengutamakan salah satu daerah saja.

e) Irama : menghubungkan dua tempat dengan variasi massa dan ruang

\section{Sirkulasi dan ketertutupan}

Menurut Ching (1979) terdapat 3 tipe sirkulasi pencapaian, yaitu :

a) Pencapaian langsung

b) Pencapaian tidak langsung

c) Pencapaian memutar

Menurut Ching (1979) derajat ketertutupan diakibatkan oleh unsur-unsur pembentuknya dan pola-pola bukaan. Semakin banyak bukaan makin kecil ketertutupan dan semakin kompleks unsur pembentuk visual membuat semakin besar ketertutupannya

\section{Kajian kawasan studi kasus}

Kawasan Kota Lama Semarang berada di sepanjang Jl. Letnan Jenderal Soeprapto, Kecamatan Semarang Utara. Kota Lama Semarang adalah sebuah kawasan di Semarang yang menjadi pusat perdagangan pada abad ke 19-20. Luas kawasan ini \pm 31 haktare. Dilihat dari kondisi geografis, nampak bahwa kawasan ini terpisah dengan daerah sekitarnya,sehingga nampak seperti kota tersendiri, sehingga mendapat julukan "Little Netherland". Menurut Rencana Tata Ruang dan Wilayah Kota
Semarang Tahun 2011-2031, kawasan Kota Lama berada di BWK III yang merupakan kawasan wisata, yaitu wisata cagar budaya

Penelitian ini bertujuan adalah untuk memperkaya teori transformasi spasial yang berkaitan dengan bentuk dan pola ruang komunal. Objek penelitian ini adalah Taman Srigunting dan Polder Tawang yang terletak di Kota Lama Semarang. Penelitian ini menggunakan pendekatan kualitatif menggunakan studi kasus.

\section{Hasil dan Diskusi}

Ruang komunal yang menjadi objek penelitian adalah Taman Srigunting dan Polder Tawang. Keduanya merupakan ruang komunal yang terkenal di Kota Lama Semarang dan banyak dikunjungi masyarakat baik domestik maupun turis mancanegara.

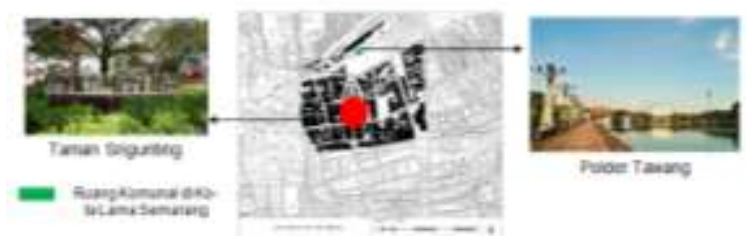

Gambar 2 Lokasi studi kasus

Sumber: dokumentasi pribadi

\section{Perubahan fungsi taman srigunting}

Taman Srigunting merupakan salah satu landmark di Kawasan Kota Lama Semarang, Taman Srigunting pada masa kolonial belanda berwujud parade plein untuk panggung parade, kini menjadi sebuah ruang terbuka berupa taman yang menjadi salah satu tempat untuk berkumpul atau berkegiatan komunitas.

Pada era kolonial pusat dari kawasan Kota Lama berada di Taman Srigunting, sebuah taman yang terletak di jantung Kawasan Kota Lama Semarang. Di masa lalu taman ini adalah sebuah lapangan bernama Parade Plein dan digunakan untuk parade militer, karena tak jauh dari sana terdapat sebuah barak militer. Sebelum menjadi lapangan, taman ini memiliki fungsi sebagai kerkhof atau pemakaman warga Eropa. Namun, seiring dengan perkembangan zaman, ruang komunal yang merupakan pusat dari kawasan Kota Lama Semarang ini berubah bentuk menjadi taman

\section{Penjelasan Transformasi pola ruang Srigunting}

Pada taman srigunting era kolonial memiliki 4 bentuk dari 7 bentuk ruang komunal Girouard (1985), yaitu :

[1] bentuk lansekap

[2] panggung, 
Transformasi Bentuk Dan Pola Ruang Komunal Di Kota Lama Semarang

[3] detil arsitektur

[4] jalur sirkulasi di dalam ruang komunal.

Pada taman srigunting era modern memiliki 5 bentuk dari 7 bentuk ruang komunal, yaitu :

[1] bentuk lansekap,

[2] panggung,

[3] zona relaksasi,

[4] detil arsitektur,

[5] jalur sirkulasi di dalam ruang komunal.

Terjadi penambahan bentuk zona relaksasi pada era modern yang disebabkan adanya perubahan fungsi dari hanya parade plan yang bersifat formal menjadi taman beraktivitas warga yang juga memiliki sifat untuk rekreasi

Bentuk bentang air dan restoran tidak pernah dirancangkan pada taman srigunting sejak zaman kolonial kemungkinan karena posisi taman yang berada di daerah rawan banjir, dan sekitar taman merupakan area perkantoran, tempat ibadah yang tidak memiliki restoran di sekitarnya.

Perubahan wujud ruang komunal taman srigunting meliputi : penghilangan sudut (non angling), pengurangan (substraction) dan pembukaan area taman dengan jalur sirkulasi dalam taman yang simetris (open).

Perubahan wujud ruang komunal tersebut dapat dideskripsikan dengan teori arsi- tektur (Ching, 1979) sebagai berikut : penghilangan sudut tegak lurus pada taman era kolonial dengan pemberian kurva menegaskan kontuinitas ruang dan kelembu- tan bentuk pada era modern. Pengurangan dimensi dengan mempertahankan ben- tuk segiempat era kolonial yang berubah menjadi bujur sangkar dipengaruhi oleh aktivitas sekitar kawasan dan bangunan yang mempersempit area taman. Pembukaan jalur sirkulasi dalam taman yang membagi menjadi 3 area simetris : 1. Panggung tengah, 4 zona relaksasi dan jaringan jalan sirkulasi dengan detail arsitektural taman menegaskan keterbukaan taman untuk dimanfaatkan masyarakat dengan 5 jaringan kluster yang dapat dipakai untuk kegiatan yang lebih mengelompok.

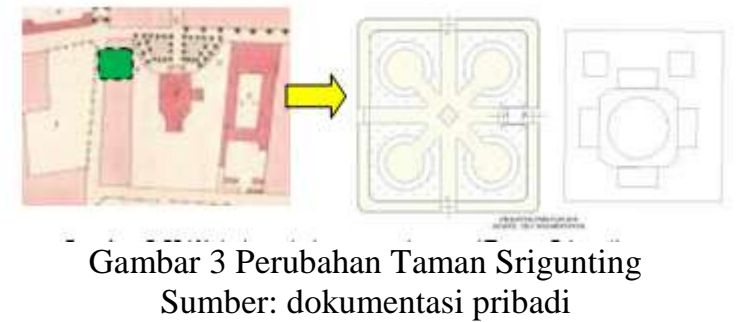

Perubahan fungsi polder tawang
Selain taman Srigunting, ruang komunal yang memiliki peranan penting dalam sejarah kawasan Kota Lama Semarang adalah area sekitar Polder Air Tawang. Sebe- lum menjadi polder, dahulu area ini merupakan lapangan dan merupaka bagian dari lansekap stasiun Tawang. Kemudian, area ini juga sempat mengalami perubahan fungsi menjadi tempat pemberhentian bus. Namun, untuk mengurangi banjir yang ser- ing melanda Semarang, maka lapangan ini berubah fungsi menjadi polder sebagai pusat pengendali banjir dan penampungan air sebelum dialirkan ke laut. Namun, saat ini polder Tawang berfungsi tidak hanya sebagai pengendali banjir, akan tetapi juga sebagai area rekreasi bagi masyarakat di sekitarnya

\section{Penjelasan transformasi pola ruang Polder Tawang}

Pada area polder era kolonial sebagai lapangan olahraga maupun terminal transportasi memiliki 4 bentuk dari 7 bentuk ruang komunal Girouard (1985), yaitu :

[1] bentuk lansekap

[2] panggung ,

[3] detil arsitektur,

[4] jalur sirkulasi di dalam ruang komunal

Sedangkan pada era modern seiring dengan perubahan fungsi menjadi polder, terdapat 6 bentuk ruang komunal, yaitu :

[1] bentuk lansekap,

[2] benteng air,

[3] panggung,

[4] zona relaksasi,

[5] detil arsitektur,

[6] jalur sirkulasi di dalam ruang komunal.

Penambahan bentang air dan zona relaksasi disebabkan adanya fungsi sebagai kolam retensi penanggulangan banjir kota lama dan fungsi objek wisata

Selain penambahan bentuk ruang komunal tersebut, perubahan wujud yang terjadi adalah : pembentukan sudut (angling), pengurangan bentuk (substraction) sehingga menjadi bentuk regular, dan penutupan area dengan menempatkan parit dan pohon pembatas di sekitar polder.

Bentuk polder yang segiempat beraturan dari bentuk semula yang iregular menegaskan fungsi polder sebagai struktur bangunan kolam masif yang penting bagi kawasan sekitarnya sehingga lansekap sekitarnya yang mengikuti bentuk baru yang memiliki 4 sudut tegak lurus ini.

Derajat ketertutupan polder modern ini secara visual tidak terlihat jelas karena hanya berbatas furnitur jalan dan pohon, tetapi pola sirkulasi 


\section{Transformasi Bentuk Dan Pola Ruang Komunal Di Kota Lama Semarang}

kawasan yang diterapkan menyebabkan area polder modern lebih tertutup dibanding era kolonial yang dapat di akses dari beberapa arah.

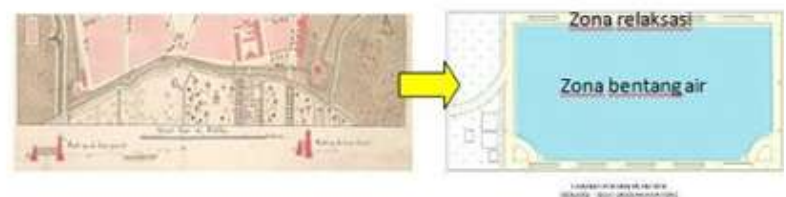

Gambar 4 Perubahan Polder Tawang

Sumber: dokumentasi pribadi

Berdasarkan analisa transformasi bentuk dan pola ruang komunal yang ada di Kota Lama Semarang, maka dapat disimpulkan bahwa wujud perubahan yang terjadi pada ruang komunal di Kota Lama Semarang adalah sebagai berikut :

Tabel 1 Perubahan fungsi, bentuk ruang, sirkulasi dan aktivitas ruang komunal kota lama Semarang

\begin{tabular}{|c|c|c|c|c|}
\hline \multirow{2}{*}{$\begin{array}{c}\text { ELEMEN } \\
\text { PERUBAHAN }\end{array}$} & \multicolumn{2}{|c|}{ Taman Srigunting } & \multicolumn{2}{|c|}{ Polder Tawang } \\
\hline & Kolonial & Modern & Kolonial & Modern \\
\hline fungsi & $\begin{array}{l}\text { kerkhof } \\
\text { kemudian } \\
\text { berubah } \\
\text { fungsi } \\
\text { menjadi } \\
\text { parade } \\
\text { plan } \\
\end{array}$ & $\begin{array}{l}\text { Sebagai } \\
\text { ruang } \\
\text { terbuka } \\
\text { taman } \\
\text { aktif }\end{array}$ & $\begin{array}{l}\text { lansekap } \\
\text { stasiun } \\
\text { Tawang }\end{array}$ & $\begin{array}{l}\text { Sebagai } \\
\text { polder } \\
\text { untuk } \\
\text { menampung } \\
\text { air }\end{array}$ \\
\hline bentuk & $\begin{array}{l}\text { Memiliki } \\
4 \text { bentuk } \\
\text { dari } 7 \\
\text { bentuk } \\
\text { ruang } \\
\text { komunal } \\
\text { Girouard } \\
(1985),\end{array}$ & $\begin{array}{l}\text { Memiliki } 5 \\
\text { bentuk dari } \\
7 \text { bentuk } \\
\text { ruang } \\
\text { komunal } \\
\text { Girouard } \\
(1985) \text {, }\end{array}$ & $\begin{array}{l}\text { Memiliki } \\
4 \text { bentuk } \\
\text { dari } 7 \\
\text { bentuk } \\
\text { ruang } \\
\text { komunal } \\
\text { Girouard } \\
(1985),\end{array}$ & $\begin{array}{l}\text { Memiliki } 6 \\
\text { bentuk dari } \\
7 \quad \text { bentuk } \\
\text { ruang } \\
\text { komunal } \\
\text { Girouard } \\
(1985),\end{array}$ \\
\hline sirkulasi & $\begin{array}{l}\text { Tanpa } \\
\text { jalur }\end{array}$ & Ada jalur & Ada jalur & Ada jalur \\
\hline aktivitas & $\begin{array}{l}\text { ziarah } \\
\text { dan } \\
\text { upacara }\end{array}$ & $\begin{array}{l}\text { Sosialisasi } \\
\text { dan } \\
\text { berkumpul }\end{array}$ & $\begin{array}{l}\text { Taman } \\
\text { pasif }\end{array}$ & $\begin{array}{l}\text { Rekreasi } \\
\text { sekitar } \\
\text { polder }\end{array}$ \\
\hline
\end{tabular}

\section{KESIMPULAN}

Berdasarkan hasil analisis data penelitian dapat disimpulkan bahwa terjadi transformasi bentuk dan pola ruang komunal di kawasan Kota Lama Semarang. Transformasi bentuk dan pola ruang komunal di Kota Lama Semarang terjadi pada beberapa elemen, yaitu:

[1] fungsi ruang komunal,

[2] bentuk ruang komunal,

[3] sirkulasi pada ruang komunal,

[4] Aktivitas yang ada di ruang komunal,

[5] Identitas.

Selain itu, dapat disimpulkan juga bahwa penataan ruang,khususnya ruang komunal di Kota
Lama Semarang bersifat homogen. Namun secara linkage ruang-ruang yang ada di kawasan Kota Lama Semarang tidak saling berhubungan, tetapi menjadi vista bagi area sekitarnya, khususnya ruang komunal yang ada di Kota Lama Semarang.

\section{REKOMENDASI}

Rekomendasi yang dapat diberikan berdasarkan hasil penelitian ini adalah sebagai berikut:

1. Dalam menata ruang komunal, khususnya ruang komunal di Kota Lama hendaknya mempertahankan bentuk kawasan Kota Lama, sehingga identitas Kota Lama tetap terlihat dan tetap selaras dengan kondisi area sekitarnya.

2. Dalam mengembangkan atau mendesain ruang komunal yang ada di Kota Lama hendaknya memperhatikan bentuk-bentuk yang sesuai dengan konteks atau citra Kota Lama sebagai kawasan cagar budaya, sehingga pola ruang komunal yang terbentuk bisa menyelaraskan dengan bangunan maupun lingkungan di Kota Lama.

\section{DAFTAR PUSTAKA}

Carmona, M., Heath, T., Oc, T. and Tiesdell, S., 2006. Public Places - Urban Spaces. The Dimension of Urban Design. Architectural Press, USA

Carr, S., Mark, F., Rivlin G.Leane and Stone M. Andrew., 1995. Public Space. Cambridge University Press, Australia.

Hakim, R. (1987). Unsur Perancangan Dalam Arsitektur Lansekap. Jakarta: Bumi Aksara.

Madanipour, A. (1996). Design of Urban Space- An Inquiry Into a Socio-Spatial Process. England: John Willey \& Sons.

Mulyo, Adiyani, Rizky.(2008). Tesis Pengaruh Fungsi Bangunan dan Activity Support Terhadap Pertumbuhan Koridor (Studi Kasus: Jl. Letjend. Suprapto Kota Semarang). Semarang: Magister Teknik Arsitektur Universitas Diponegoro Semarang.

Rapoport, A. 1969. House, Form, and Culture, Design, Edgewood Cliffs: Prentice Hall.

Rapoport. A., 1977. Human Aspect of Urban FormTowards a ManEnvironment Approach to Urban Form and Design, Pergamon Press Ltd., Headington Hill Hall, Oxford, England.

Sarwono, Sarlito. Wirawan. 1992. Psikologi Lingkungan. Grasindo PT Gramedia Widiasarana Indonesia: Jakarta.

Sugiyono .2010. Metode Penelitian Kuantitatif Kualitatif \& RND. Bandung : Alfabeta 
Transformasi Bentuk Dan Pola Ruang Komunal Di Kota Lama Semarang

Shirvani,Hamid, 1985, The Urban Design Process.

Van Nostrand Reinhold Company Limited, New York

Zahnd, Markus. 1999. Perancangan Kota Secara

Terpadu. Yogyakarta : Kanisius 